\title{
BRIDGING ENGLISH AND BULGARIAN INTENSIFIERS AND ADJECTIVES
}

\author{
Irina Stoyanova-Georgieva*
}

\begin{abstract}
It is perfectly natural that users of English and Bulgarian alike find some combinations of intensifiers and adjectives possible while others sound too strange to be used. The paper deals with the constraints that govern the collocation of intensifiers and adjectives in English and in Bulgarian and proves that these restrictions are predictable and lie in conceptualisations of both constituents. What is more, the study proves that the same criteria that govern the classification of English intensifiers into paradigms of similar degree are valid for their Bulgarian translation equivalents. The same is demonstrated for the English adjectives and their Bulgarian counterparts. As a result, the study maps the similarities between the way English and Bulgarian collocations are formed and provides working, trustworthy models for classification of Bulgarian adverbs and adjectives.
\end{abstract}

Key words: adjectives, intensifiers, collocations

\section{Introduction}

Many scientists believe that there are certain restrictions on the connections between linguistic items. Some of them speak of incompatibility as a general term: some intensifiers are capable of qualifying numerous words, while 'many are restricted to a small set of lexical items' (see Quirk et al., 1993, p. 116). Others point out that it is the meaning of the items that presupposes the inability of certain gradable adjectives to combine with all degree modifiers (see Paradis, 1997, p. 41), and that 'the conceptualization of the adjective' should 'harmonize with that of the degree modifier' (op. cit., p. 159). It is natural to assume that the essence of the restrictions lies in the semantics of the two constituents, not only one of them as Paradis righteously postulated (op. cit., pp. 158-163) and that this should be valid for Bulgarian adverbs and adjectives as well.

\section{Previous research in the field}

As far as intensification is concerned two conflicting theories exist. The first one suggests that adverbs with reinforcing and downtoning nature should be covered by different terms, while the second one treats all adverbs of degree as belonging to a single category. Stoffel (1901) was one of the first to make a semantic distinction between "intensives and down-toners" (p. 1), expressing

\footnotetext{
* Assistant at Shumen University, Department of English Studies, Shumen, Bulgaria, email: i.stoyanova-georgieva@shu.bg.
} 
high and respectively low degree. His position was strengthened by those of Borst (1902), Kirchner (1955), Cliff (1959), Spitzbardt (1965); Biedermann (1970), Benzinger (1971), Bolinger (1972), Bäcklund (1973), Vermeier (1979). Similar was the position supported by Biber, Conrad and Leech (2002). Despite this, others like Quirk et al. (1985) united reinforcing and attenuating nature under a single term modifier, so did Allerton (1987) calling them intensifiers, Halliday (2004) using submodifiers or qualifier intensifiers, and Paradis (1997) applying degree words and degree modifiers. As can be seen, the interpretations vary, and so do the cover terms employed but it seems that despite the differences the term intensifier dominates over the others.

Another common trait uniting most of the researchers is that from the point of grammar adverbs acting as modifiers of adjectives are among the most prominent forms of intensification (see Bolinger, 1972; Bäcklund, 1973, p. 279; Foley and Hall, 2003, pp. 232-233; Murphy, 2010).

But despite the fact that intensification is a popular topic of studies there are not many detailed and reliable models for classification of the adverbs of degree. One of the most popular belongs to Quirk et al. (1985, pp. 445-6, 589). According to them modifiers can be organised into two binary opposing groups - amplifiers and downtoners. The first one can be further divided into maximizers and boosters, while the second one contains items functioning as approximators, compromisers, diminishers, and minimizers, respectively. Unfortunately, despite the overall look of scalarity and adherence of the items to specific predefined rules, no hard and fast regulations for the classification of adverbs can be found in this model. Allerton (1987), on the other hand, presented a tailored classification of degree modifiers of adjectives aimed at distinguishing subgroups according to a gradable feature. He proposed the existence of three types of modifiers: scalar, telic, and absolutive. Unfortunately, despite its many priorities Allerton's framework still lacks a division according to the intensifying force of the groups. Thus, a third, more precise and comprehensive model, was searched for. One that can cover each of the characteristics of the intensifiers and the items that collocate with them. Such is considered to be the model of Carita Paradis (1997). It establishes a characterisation influenced both by Allerton's, Quirk et al.'s, and by a third model, called the scale model'. Paradis's division contains five paradigms arranged in two groups reinforcers (maximizers and boosters) and attenuators (moderators, approximators, and diminishers), the members of which express more or less the same degree and form a cline starting with the strongest reinforcing modifiers and ending with those signalling intense attenuation. Her model fills in the blank in Quirk et al.'s

\footnotetext{
* Called the scale model by Paradis, this model presents the members of the category as 'related to one another in a scalar fashion from modifiers which indicate a highly reinforcing value to items which indicate an attenuating position.
} 
and Allerton's models expressing that 'the use of degree modifiers is constrained by the semantic features of the collocating adjective in two dimensions: totality and scalarity. She also insists that 'the relation between the semantic features of the adjective and its modifier has to be harmonious' (op. cit., p. 26) and presents the paradigms as forming a scale starting with the highest degree and slowly going down to the lowest. This introduces two visualisations of the model.

Table 1. Imagined scale of degree modifiers according to Paradis (1997)

\begin{tabular}{ll}
\hline $\begin{array}{l}\text { REINFORCERS } \\
\text { Maximizers } \\
\text { Boosters }\end{array}$ & $\begin{array}{l}\text { quite, absolutely, completely, perfectly, totally, entirely, utterly } \\
\text { very, terribly, extremely, most, awfully, jolly, bighly, frightfully }\end{array}$ \\
\hline $\begin{array}{l}\text { ATTENUATORS } \\
\text { Moderators and Approximators }\end{array}$ & $\begin{array}{l}\text { quite, rather, pretty, fairly, almost } \\
\text { Diminishers }\end{array}$
\end{tabular}

Table 2. The paradigms divided according to scalarity and totality according to Paradis (1997)

\begin{tabular}{|c|c|c|}
\hline Reinforcers & maximizer & quite, absolutely completely perfectly, totally, entirelys utterly \\
\hline Attenuators & approximators & almost \\
\hline \multicolumn{3}{|c|}{ SCALAR MODIFIERS } \\
\hline Reinforcers & boosters & verys terriblys extremelys most, aufully, jollys highly frightfully \\
\hline \multirow[t]{2}{*}{ Attenuators } & moderators & quite, nather, pretty fainly \\
\hline & diminishers & a (little) bit, slightly a little, somewhat \\
\hline
\end{tabular}

Bulgarian researchers, on the other hand, expressed the opinion that intensifiers belong to a class denoting quantity and degree (see Andreychin, 1978, p. 323; Tilkov, Stoyanov, and Popov, 1983, pp. 391-398; Boyadzhiev, Stoyanov, and Popov, 1998, p. 353). They also clarify that the adverbs, placed in front of the adjective they modify, are predominantly degree adverbs and as such they are called degree modifiers (see Boyadzhiev et al., 1998, p. 530). What is more, according to Tilkov et al. (1983, pp. 393-398) most adverbs of grade and degree, except for много, derive mainly from adjectives. Moreover, Pashov (2005) stated that the adverbs of quantity and grade are the most common and natural modifiers of adjectives due to the fact that almost all of the qualities, expressed by adjectives, can have a higher or lower degree. According to Popov (1983), adverbial modifiers of grade represent a graded evaluation of the action in comparison with another action and can also be divided into two categories: adverbial modifiers of high grade and adverbial modifiers of low grade (see Tilkov et. al., 1983, p. 205).

Taking into consideration the above-mentioned theories, I suppose that there is a great proportion of overlap between the qualities ascribed to the English and the Bulgarian adverbs. Firstly, most of the representatives of both groups originate from adjectives. Secondly, Bulgarian and English researchers alike 
state that the adverbs of degree are the most common and natural modifiers of adjectives. But since Bulgarian linguists ventured no further than drawing a line between reinforcing and attenuating items there is no full overlap between the theories for the scales of gradability.

As a result, I believe that the items acting as intensifiers in both languages are comparable and thus capable of fitting into the same categories. But as adverbs are not the only member of the collocation adjectives should be classified too.

As was mentioned, adverbs of degree have been the subject of many interpretations but it is their co-occurrence with adjectives, the second and active constituent in the collocations, that is 'crucial for their interpretation' (see Paradis, 1997, p. 18).

According to Quirk et al. (1985) adjectives have to be in some way gradable, in order to be modified by an adverb of degree and hypothesised that there are four criteria characterising the lexemes (1985, p. 403). Collins Cobuild English Grammar divided the items into qualitative and classifying. (1990, pp. 63-65). Paradis, however, proposed a fuller, more exhaustive qualification based on Allerton's model (see Allerton, 1987, p. 20) and assumed that gradable adjectives can fall into three basic types: scalar, extreme, and limit (see Paradis, 1997, p. 48). And since the conceptualisation of the members of each type of gradable adjective is decisive for the choice of degree modifiers, the analysis of the various types of adjectives should be done in combination with degree modifiers.

Table 3. Paradis's criteria for the division of adjectives into scalar, extreme, and limit adjectives and the types of degree modifiers they combine with

(see Paradis 1997: 161)

\begin{tabular}{llll} 
Defining features & Scalar adjectives & Extreme adjectives & Limit adjectives \\
\hline Comparison & yes & yes/no & no \\
'How $\mathrm{x}$ is it?' & yes & no & no \\
'How x!' & yes & yes & no \\
Oppositeness & antonymy & antonymy & complementarity \\
& & & \\
Degree modifiers & scalar modifiers & totality modifiers & totality modifiers \\
\hline & boosters & maximizers & maximizers \\
& moderators & + most & approximators \\
& diminishers & &
\end{tabular}

Very similar to Collins Cobuild English Grammar (1990, p. 65) Pashov, too, organised Bulgarian adjectives into qualitative and relative (качествени и относителни). According to him, qualitative adjectives are items denoting qualities which are intrinsic to the nouns and are activated independently of other nouns. Relative adjectives, on the contrary, acquire their qualities due to their relations with other nouns. As such relative adjectives do not possess the 
semantic feature of gradability (see Pashov, 2005, pp. 81-82). This classification also corresponds to Paradis's. It can be easily deduced that the category of relative adjectives in Bulgarian corresponds to the category of non-gradable ones in English, while the group of qualitative conforms to the group of gradable adjectives. It is probable that the distinction between scalar, extreme, and limit adjectives could be applied to the Bulgarian adjectives, occurring in this study.

The combination of these two elements will be examined under the term collocation, adopted from John Firth (1968, p. 182) and recognized by Stubbs (1995). It states that collocations are 'actual words in habitual company'.

\section{Corpus, research tools, and methods of analysis}

The corpus of the study is constructed on the basis of 1200 letters to the editor extracted from 4 British (The Financial Times, The Independent, The Guardian, and The Daily Express) and 4 Bulgarian newspapers (24 chasa, Dnevnik, Duma, and Lichna drama), as well as 2 British (The Economist and The BBC Focus) and 2 Bulgarian (Tita and National Geographic) magazines. It was assembled in such a way as to guarantee full coverage of the types of print media existing in both countries and is often referred to as the LtE corpus.

Due to the specificity of the analysis and the small size of the corpus, namely 345222 tokens (words), 252906 building the Bulgarian subcorpus and 92316 making the English one, several research tools are needed in order to achieve maximum reliability of the results. But the study also relies on informants which provide the necessary information lacking in the research tools.

The first research tool is the Bulgarian WordNet, a lexico-semantic net consisting of cognitive synonym sets (synsets) (see http://dcl.bas.bg/elektronni-ezikoviresursi-i-programi-za-tyahnata-obrabotka-bulnet-i-freymnet/). Every synset encodes an equivalence relation between several items (literals) which have a similar meaning and belong to one and the same part of speech (see Dekova, 2011, p. 288). What is more, every synset is related to a corresponding synset in the Princeton's WordNet (PWN2.0).

The second one is the British National Corpus (BNC), a monolingual and synchronic collection of words. As such it provides an opportunity for examination of the frequency of the investigated intensifiers in similar media texts, and in the general language.

The last research tool is the Bulgarian National Corpus (BulNC). A monolingual synchronic collection of more than 470 million words from over 10000 texts. It represents Bulgarian from 1945 until the present days and its unique nature turns it into a suitable reference tool for the Bulgarian section of this study. 
Finally, themethods employed in the currentstudy are: qualitative and quantitative analysis, informant testing, introspection, and corpus-based observations.

\section{Data analysis}

Because of the large number of degree adverbs and the fact that their quantity is ever growing due to new coinages (see Murphy 2010) the number of researched items had to be somehow limited so as to ensure reliability of the results. Thus, the focus of the study is put on 20 of the most popular and widely known intensifiers (absolutely, completely, totally, very, extremely, so, highly, really, too, quite, rather, pretty, fairly, relatively, almost, nearly, hardly, a bit, a little, somewhat) and the adjectives they modify.

\subsection{Intensifiers}

The lack of consistent treatment of all of the chosen items according to the criteria listed in Paradis's study (1997) demanded that all 20 degree adverbs should undergo a classification procedure. And as none of the theories provides full insights into the process of categorisation the following strategy is followed. Namely, the study uses the synonyms of the degree adverbs, extracted from the Oxford English Dictionary, to map the adverbs into categories corresponding to their meaning. The careful examination of the cognitive synonyms of each adverb shows a strange interdependence between the synonyms, namely the percentage of coincidence between the synonyms of each intensifier, and the designated place of this intensifier in the classification.

This means that starting from the highest possible position on the scale (absolutely) each successive member of the paradigm supplements an additional synonym or leaves out one from the previous set. This change goes on until the set of synonyms of the last word differs substantially from that of the first member of the paradigm. In this way the members of the paradigms of intensifiers are determined. Moreover, as the synonyms appear in a slowly decreasing scale, the intensifier which appears next in line normally appears as one of the synonyms of its previous adverbs. Based on this Figure 1 was compiled placing the items subject of this study in one of the 5 paradigms of Paradis.

Up to now no information was given on the corresponding Bulgarian set of intensifiers needed for the comparative nature of the research. As the English set of intensifiers plays the role of a pivot for the study, the Bulgarian set is constituted by choosing the closest and most appropriate translations of each of the members in the English set. Thus, a group of 50 informants* is asked

\footnotetext{
* All of the informants are native Bulgarian speakers and students at Konstantin Prelavsky University of Shumen (35 1st year, 2 3rd year English Studies students as well as 13 1st year Applied Linguistics students). Their English language proficiency was rated accord-
} 
to provide their understanding and translation of the 20 adverbs of degree. They are handed the test materials individually, each adverb, adjective, and collocation is 'translated' by at least 3 independent informants. The results are further examined against the information given in BulNet, which due to its connection to the Princeton Wordnet provides not only the Bulgarian Synsets of each searched item, but also its English counterparts, and vice versa. As a result of this, Table 4 contains the Bulgarian intensifiers further investigated in the study.

Table 4. English intensifiers and their Bulgarian counterparts

\begin{tabular}{|c|l|l|}
\hline No & English intensifier & Bulgarian intensifier \\
\hline 1. & absolutely & абсолютно \\
\hline 2. & completely & съвършено, напълно \\
\hline 3. & extremely & изключително \\
\hline 4. & totally & напълно \\
\hline 5. & very & много \\
\hline 6. & highly & извънредно \\
\hline 7. & really & наистина \\
\hline 8. & pretty & твърде, доста \\
\hline 9. & so & така \\
\hline 10. & too & прекалено \\
\hline 11. & almost & почти \\
\hline 12. & quite & съвсем, твърде, доста \\
\hline 13. & rather & доста, твърде \\
\hline 14. & fairly & сравнително \\
\hline 15. & relatively & относително, сравнително \\
\hline 16. & hardly & едва \\
\hline 17. & nearly & почти, приблизително \\
\hline 18. & a bit & малко, мъничко \\
\hline 19. & a little & малко \\
\hline 20. & somewhat & до известна степен, малко, доста \\
\hline
\end{tabular}

The next step in the research is the allocation of each of the Bulgarian adverbs into one of Paradis's paradigms. As the process is entirely based on the model applied for the English degree adverbs, the same procedure is followed for the Bulgarian items where again BulNet is consulted. This classification, aiming to stratify adverbs of degree into several different scales, signalling different force

ing to the Common European Framework of Reference for Languages principles and was estimated to be either B2 or C1. 
and direction in the cline of intensification, presents the examined lexemes from an original perspective.

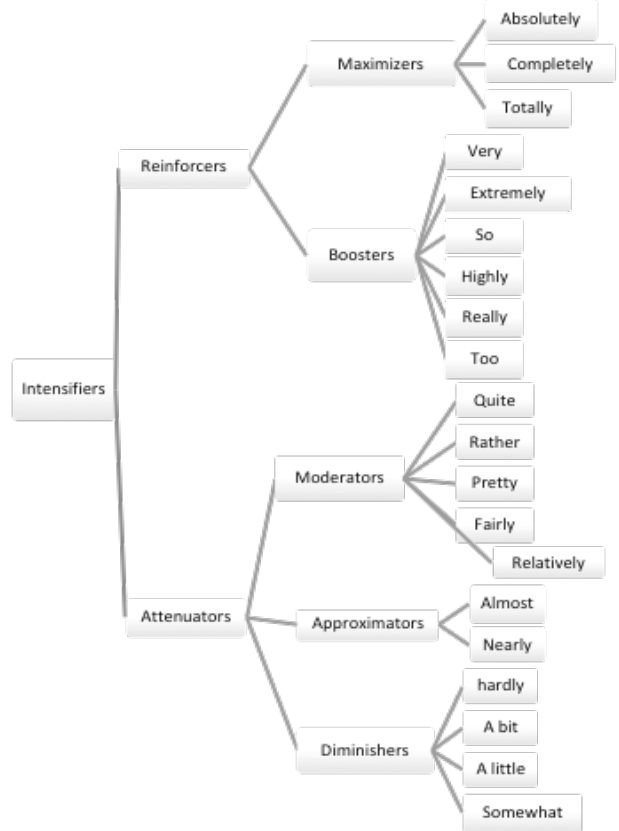

Figure 1. The five paradigms of English intensifiers

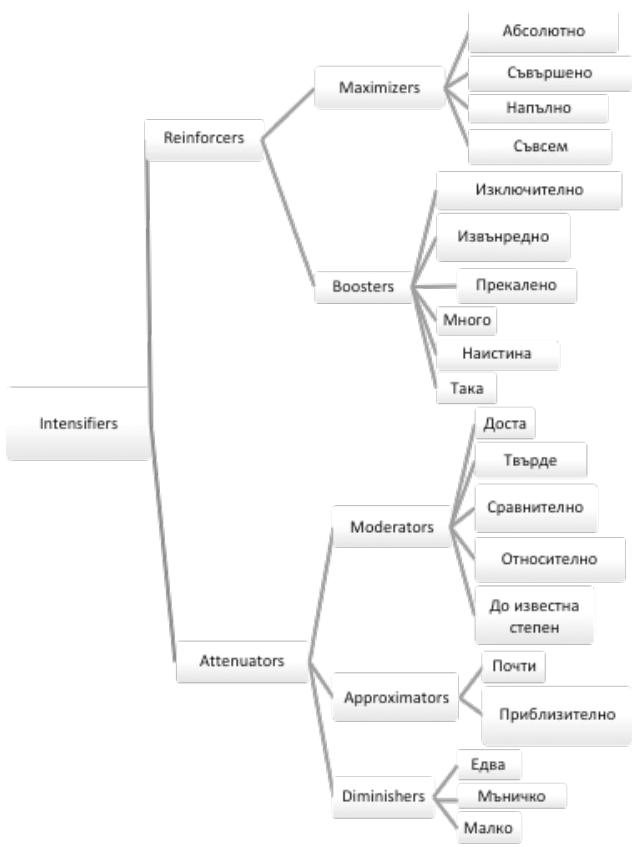




\section{Figure 2. The five paradigms of Bulgarian intensifiers}

Both sets of adverbs are almost the same, the differences between them are only minor. It should be noted that both English correspondents of съвсем and до известна степен have a double nature which fits into the originally ascribed pattern of the English adverb, as well as into the one newly ascribed to the Bulgarian adverb. Despite this, it can undoubtedly be deduced that the Bulgarian adverbs of degree can also be assigned into groups signalling different degrees; what is even more important, they can be fitted seamlessly into the model applicable to the English intensifiers. What is even more important is that a working model for the effortless and trustworthy classification of English adverbs of degree is provided.

\subsection{Adjectives}

According to Paradis, adjectives as well as intensifiers can be classified. Her model presented them as scalar, extreme, and limit. In tune with this, scalar adjectives can be accompanied by scalar modifiers (boosters, moderators, and diminishers), extreme adjectives should be preceded by maximizers, and limit adjectives are qualified by two types of totality modifiers - maximizers and approximators. In order to be allocated to one of these groups an adjective should be assessed according to a list of defining features (see Paradis, 1997, p. 49). First and foremost, they have to be gradable (op. cit., p. 41) as non-gradable adjectives do not typically tolerate premodification by intensifiers. Gradability, on the other hand, has traditionally been explained through the word's ability to undergo comparison (see Quirk et al., 1985, p. 403; Collins, 1990, p. 65); as such it is the initial criterion indexed by Paradis. As a second specification she proposes the ability of certain adjectives to fill in the slot in How $x$ is it? sentences which imply the use of an intensifier to indicate the range of the degree. While the third one implies the ability of an adjective to act as a focus of exclamatory utterances - and How x!. The fourth indicator, measures the oppositeness involved, and thus the existence of antonyms. The positive answer to all four criteria signals a scalar adjective.

The classification of the adjectives into three main sub-groups requires an extensive comparison between the characteristics of English and Bulgarian adjectives. As with English gradable adjectives Bulgarian qualitative adjectives possess the semantic component of gradability which entails comparability of the adjectives (see Tilkov et al., 1983, p. 148). But just like Collins (1990) and Quirk et al. (1985) Tilkov et. al. did not provide an extensive characteristic of the possible differences among adjectives, but presented only such which are described as scalar ones in English. They pointed several types of adjectives, 
such as those designating colours, as well as бос (barefoot"), мъртъв (dead), жив (alive) that cannot be classified as scalar. It is an interesting occurrence that the English equivalents of the last two Bulgarian adjectives are also incapable of undergoing comparison and are classified as limit adjectives. Secondly, they stated that qualitative adjectives can express various nuances and grades of the given quality through the formation of new adjectives with the help of prefixes and suffixes. As such they can attempt to answer the question How x is it?. And finally, they stated that some of the qualitative adjectives have antonyms and form antonymic pairs.

Taking into consideration the abovementioned statements about Bulgarian adjectives, and the fact that they have the same semantic characteristics, prompts the assumption that they can easily be subjected to the same classification as their English equivalents. The only component missing from the qualification is the ability to express exclamation. This, though not mentioned, is effortlessly deduced as perfectly possible as: Колко красиво!, Колко прекрасно!, Колко грозно! are examples of normal everyday language.

The first sub-category put forward by Paradis is that of scalar adjectives (1997, p. 51), where six adjectives are proposed as its representatives: good, fast, long, difficult, nasty, and interesting. According to BNC some of these lexemes have extremely high frequency with good's results soaring to 79878 uses in the corpus. This points to the conclusion that these words are among the most widely used in the English language. The same thing is also valid for their Bulgarian equivalents - добър, бърз, дълъг, труден, неприятен, and интересен (see http://search.dcl.bas.bg), where добъp is again the leading form among them with 32185 hits in the corpus. As a result, 5 of them are found in the LtE corpus of the present study and as such should be the first to undergo the procedure for establishing compatibility.

The first criterion, which covers the ability to undergo comparison, is expressed through the use of the particles: no- and най- in Bulgarian (see Tilkov et al., 1983, $\mathrm{p}$ 177). All of the examined 5 adjectives form the comparative and the superlative degree - по-дълъг, най-дълъг, по-неприятен, най-неприятен, по-бърз. The second specification is the How $x$ is it? question, the positive reaction to which also guarantees a scalar nature. In Bulgarian, the question may be rendered as: Колко е $x$ ? Bulgarian adjectives make no exception and require the use of intensifier, e.g. Колко добър е преподавателят? - Много/изключително/ сравнително добър., Колко дълъг е филмът? - Много/твърде/относително дъльг. Once again, all the adjectives answer the criterion.

* All translations of Bulgarian adjectives are done by the author of this study. 
The third norm governs the capacity of the adjective to enter into exclamatory expressions: Какво добро дете!, Колко дълга рокля!" which is again fulfilled.

The fourth rule has to do with oppositeness. As with their counterparts the 5 Bulgarian adjectives also have antonyms: добър -лош; дълъг-къс; труден лесен; интересен - безинтересен, неприятен - приятен.

Based on the abovementioned analysis all of the 5 words can be classified as strictly scalar adjectives, occupying a range along a scale according to the Paradis's criteria (1997, p. 161). The final proof of the compatibility of the present characteristics with the Bulgarian class of adjectives should be the correspondence between the preference for intensifiers in English and Bulgarian. The LtE contains 27 collocations of добър, бърз, дълъг, труден, неприятен, and интересен:

Последва изключително дьлга лекция защо трябва да гласува на предстоящите избори за Европарламент. (Then there was an extremely long lecture on why we should vote at the forthcoming elections for members of the European Parliament. - trans. author's) (see 24 chasa, 14/05/2014)

(много трудно решение!) и сигурно няма да издържа и още преди есента ще ги наредя в буркани. (a very difficult decision! and I won't stand the strain for sure and I'll put them in jars even before autumn comes. - trans. author's) (see Duma, 15/08/2013)

Examples from LtE corpus show that Bulgarian scalar adjectives just like their English counterparts are modified by boosters, diminishers, and moderators (много голям/добър/висок, твърде любопитен/зает, малко смутени/ объркани).

The second subtype distinguished by Paradis is that of extreme adjectives. But although Paradis tolerates the idea of comparable extreme adjectives (op. cit., p. 56), the idea of comparison seems incompatible. The reason is in the mental image extreme/extremity constructs, implying the idea of the farthest points reachable on a scale. I believe that Bulgarian speakers are very sensitive to it, as one can never say Петър получи по-отлична оценка от Иван. (Petar received a more excellent mark than Ivan. - trans. author's) Unfortunately, of all six adjectives studied by Paradis only huge has an equivalent in the Bulgarian section of the LtE corpus - огромна.

...императорът прехвърлил в Тракия и отправил към Онгъла наистина огромна армия... (...the emperor transferred to Trakiya and led a really huge army to the Ongal ... - trans. author's - see Dnevnik, 05/06/2014)

* The exclamation is better understood if the adjective is accompanied by its head. 
The question Колко ex?, is defined as inapplicable for English extreme adjectives due to their utmost degree, already implying the highest point on a scale. The same is true for their Bulgarian equivalents: Колко е огромна?, Колко е отлична?. However, Какво огромно здание!, Какво отлично представяне! actually exist.

Finally, огромна also has an antonym - миниатюрна, although the BulNC gives no explicit information of its antonyms.

In other words, the Bulgarian equivalent of huge - огромна, can be classified as fitting the criteria for extreme adjectives, too. Unfortunately, Paradis's assumption for the collocation of extreme adjectives with maximizers only is not confirmed by the LtE corpus. The maximizers studied in this research do not collocate with огромна as the only example is of a booster modifying it (cited above in the text). That is why the BulNC is consulted but it too shows no collocations with the maximizers analysed in this study: абсолютно, съвъриено, наистина, and съвсем.

The third group is formed by limit adjectives which are conceptualised in terms of 'either-or' (op. cit., p. 57). Such should be their interpretation in Bulgarian since one can either be жив or мъртъв, верен оr грешен. Once again due to the limitations of the LtE corpus, posed by its size, there are only two adjectives that can be considered translations of the lexemes used in Paradis's work. They are вярно and същия as in some of the examples:

Само след година обаче бях наясно, че е почти същият пияница като Наско и не пропуска чуждо като Кирил. (But it took me only a year to find out that he was almost identical with Nasko, who was a drunkard, and Kiril, who was a womanizer. - see Lichna Drama, is. 11 (1032) 1824/03/2014)

Последното може да е клише, но е абсолютно вярно в случая. (The last thing may be a cliché but is absolutely true in this case. - trans. author's, see 24 chasa, 03/04/2014)

When analysed separately the two adjectives are found to be incompatible with the criterion for comparability:

* ${ }^{*}$ по-вярно, *най-вярно; *по-същия , *най-същия.

They are also inconsistent with the Колко е $x$ ? as well as with the exclamatory Колко х! (ор. cit., p. 58).

*Колко е умрял? *Колко е достатъчен?

*Колко жив човек! *Колко верен отговор!

In terms of oppositeness Bulgarian limit adjectives differ in grammatical terms from their English counterparts, as the former possess antonyms which

* The asterisk symbolises the improbability of the example. 
were listed above. Despite this they can still be considered mutually exclusive. And although they are termed antonyms in Bulgarian, they answer the complementarity criteria posed by Cruse, where the denial of one of such terms entails the use of the other, as well as the anomalous nature of one sentence containing both opposing lexemes at one and the same time (1986, pp. 198204).

Paradis (1997) also elaborated that 'pairs of opposites are not always from the same group of adjectives' and 'a limit adjective can also form a pair with a scalar adjective, e.g. sober as opposed to drunk' (p. 58). Unexpectedly, this is indeed valid for Bulgarian too, and the deviation is obvious with the pairs същия - различен, трезвен - пиян; the second constituents of which have a distinctly scalar reading, as they can be both compared and can take part in exclamations, and evaluations of the range of their degree.

Last but not least, a comparison between the intensifiers used with these adjectives in the two languages has to be made. The study of the examples, extracted from the LtE corpus, shows that there is a perfect match between the preference for intensifiers in both languages - maximizers and approximators absolutely, almost.

In conclusion it should be said that the Bulgarian adjectives discussed here have so similar characteristics to their English counterparts that they can be assigned to the same sub-type of limit adjectives.

Given all the above-mentioned analysis, I presume that Paradis's characteristic is fully applicable to Bulgarian allowing a fully-fledged contrastive analysis and bridging of the English and Bulgarian classes of adjectives to be made.

\section{Conclusion}

The analysis of the results of the study shows that just like their English counterparts the Bulgarian adverbs of degree can also be divided into groups signalling different degrees. What is even more important is that they can be fitted seamlessly into the model applicable to the English intensifiers. Surprisingly enough, English and Bulgarian translation equivalents belong to the same subcategories forming a perfect alliance.

The study also proved Bulgarian adjectives are fully compatible with the general combinatory principles of their English counterparts. Namely, Bulgarian scalar adjectives, just like their English translation equivalents are modified predominantly by scalar modifiers, i.e. boosters, moderators, and diminishers, and limit adjectives by totality qualifiers (maximizers and approximators). The only incompatibility is found with extreme adjectives but since the size of the LtE corpus does not allow further analysis no conclusions can be made. 
One of the most significant contributions of the present study is that a working model for the effortless and trustworthy bridging of English and Bulgarian intensifiers and adjectives was established.

\section{References:}

Allerton, D.J. (1987). English intensifiers and their idiosyncrasies. In R. Steele \& T. Threadgold (Ed.), Language topics. Essays in honour of Michael Halliday, (pp. 15-31). Amsterdam: John Benjamins.

Andreychin, L. (1978). Osnovna balgarska gramatika. Sofia: Nauka i izkustvo.

Bäcklund, U. (1973). The collocation of adverbs of degree in English. Studia Anglistica Upsaliensia 13. Uppsala: Almqvist \& Wiksell.

Benzinger, E. M. (1971). Intensifiers in current English. University of Florida. Retrieved from https://archive.org/stream/intensifiersincu00benz/intensifiersincu00benz_djvu.txt

Biber, D., Conrad, S., \& Leech, G. (2002). A student grammar of spoken and written English. London: Longman.

Biedermann, R. (1970). Die Deutschen Gradadverbien. Diss. Heidelberg.

Bolinger, D. L. (1972). Degree words. The Hague: Mouton.

Borst, E. (1902). Die Gradadverbien im Englischen. Anglistische Forshungen 10. Heidelberg: Carl Winter.

Boyadzhiev, T., Stoyanov, S., \& Popov, K. (1998). Gramatika na savremenniya balgarski knizhoven ezik. V tri toma. Tom 3. Sintaksis. София: Абагар.

British National Corpus. Retrieved from https://corpus.byu.edu/bnc/

Bulgarian National Corpus. Retrieved from http://search.dcl.bas.bg

BulNet. Retrieved from http://dcl.bas.bg/bulnet/

Cliff, N. (1959). Adverbs as multipliers. Psychological Review. 66, 27-44.

Collins Cobuild English grammar. (1990). Ed. by John Sinclair. London: Collins.

Cruse, D. A. (1986). Lexical Semantics. Cambridge: Cambridge University Press.

Dekova, R. (2011). Balgarskoto ezikoznanie v savremenniya svyat-balgarskiyat natsionalen korpus. Yubileyni paisievi cheteniya. Universitetat akademichna karta na sveta. 49, 287305.

Firth, J. (1968). A Synopsis of Linguistic Theory, 1930-55. In F. R. Palmer (Ed.), Selected Papers of J. R. Firth (1952-59) (pp. 168-205). London: Longman

Foley, M., \& Hall, D. (2003). Longman Advanced Learners' Grammar. Essex: Pearson Education Limited.

Halliday, M. \& Matthiessen, C. (2004). An Introduction to Functional Grammar. London: Hodder Arnold.

Kirchner, G. (1955). Gradadverbien: Restriktiva und Verwandtes im heutigen Englisch. Halle: Max. Niemeyer Verlag.

Murphy, B. (2010). Corpus and Sociolinguistics: Investigating Age and Gender in Female Talk. Amsterdam: John Benjamins.

Oxford English Dictionary online. Retrieved from https://en.oxforddictionaries.com 
Paradis, C. (1997). Degree modifiers of adjectives in spoken British English. Lund: Lund University Press.

Pashov, P. (2005). Balgarska gramatika. Plovdiv: Hermes.

Popov, K. (1983). Gramatika na savremenniya balgarski knizhoven ezik-Sintaksis. Sofiya: Izdatelstvo na BAN.

Quirk, R., Greenbaum, S., \& Svartvik, G. (1985). A comprehensive grammar of the English language. Essex: Longman.

Spitzbardt, H. (1965). English adverbs of degree and their semantic fields. Philologica Pragensia, 8, 349-359.

Stoffel, C. (1901). Intensives and down-toners: a study in English adverbs. London: Forgotten Books.

Stubbs, M. (1995). Collocations and semantic profiles. Functions of language. 2:1, 23-55.

Princeton University WordNet. Retrieved from http://wordnetweb.princeton.edu/perl/ webwn

Tilkov, D., Stoyanov, S., \& Popov, K. (1983). Gramatika na savremenniya balgarski knizhoven ezik, tom 2 Morfologiya. Sofiya: Balgarska akademiya na naukite.

Vermeire, A. (1979). Intensifying adverbs. Unpublished PhD thesis in the Department of Linguistics and Modern English Language. University of Lancaster. 